\title{
Modulation of a Voltage-activated Potassium Channel by Peptide Growth Factor Receptors
}

\author{
Leslie C. Timpe ${ }^{1}$ and Wendy J. Fant ${ }^{2}$ \\ ${ }^{1}$ Program of Excellence in Molecular Biology, Cardiovascular Research Institute, and ${ }^{2}$ Department of Medicine and \\ Cardiovascular Research Institute, University of California at San Francisco, San Francisco, California 94143
}

\begin{abstract}
Regulation of the activity of a cloned component of a voltageactivated $K^{+}$channel, $K_{v 1.5}$, was studied by expressing the $\mathrm{K}^{+}$channel and receptors for platelet-derived growth factor (PDGF) or fibroblast growth factor (FGF) simultaneously in Xenopus oocytes. Receptor activation mediated a decline in the $K_{v 1.5}$ current amplitude, with a half-time of about 20 $\min$. The reduction in $K^{+}$current amplitude occurred with little change in the kinetics or voltage sensitivity of activation. A similar phenomenon was found when the human thrombin or rat 5-HT ${ }_{1 \mathrm{c}}$ receptors, two receptors that increase phospholipase $C$ activity, were tested in coexpression experiments. A mutant FGF receptor, which does not activate phospholipase $\mathrm{C}-\gamma 1$ but retains several of its other functions, did not modulate the $K_{\mathrm{v} 1.5}$ current. Simultaneous injection of inositol trisphosphate and superfusion of phorbol 12myristate 13-acetate reproduced the modulation of the $K_{v 1.5}$ current. These results demonstrate that the PDGF and FGF receptors can modulate a voltage-activated $K^{+}$channel by increasing phospholipase $\mathrm{C}$ activity, and suggest that PDGF or FGF may be able to alter rapidly the electrical excitability of neurons.
\end{abstract}

[Key words: potassium channel, platelet-derived growth factor, fibroblast growth factor, growth factor receptors]

Modulation of ion channel activity by neurotransmitter or hormone receptors is an important and widespread means of altering electrical activity in neurons (Kaczmarek and Levitan, 1987). Examples of modulation are known for $\mathrm{Ca}^{2+}$ channels and for a wide variety of $\mathrm{K}^{+}$channels, including those activated by voltage. For example, in the dorsal raphe nucleus and hippocampus of the rat, stimulation of $\alpha_{1}$-adrenoreceptor or muscarinic receptors, respectively, reduces the amplitude of a voltage-activated $\mathrm{K}^{+}$current, thereby accelerating the rate of repetitive firing (Aghajanian, 1985; Nakajima et al., 1986). Dubinsky and Oxford (1985) have shown that one of the cffects of thyrotropin-releasing hormone (TRH) in a pituitary cell line, an increase in action potential duration, results from the decrease in the amplitude of a slowly inactivating $\mathrm{K}^{+}$current. Not all cases of modulation of voltage-activated $\mathrm{K}^{+}$channels lead

\footnotetext{
Received Jan. 28, 1993; revised June 30, 1993; accepted Aug. 10, 1993.

We thank Shaun Coughlin, David Julius, Leonard Kaczmarek, and Kevin Peters for clones, John Fenton for thrombin, Katherine Logee for technical assistance, and Rusty Williams for cncouragement. This work was supported by NIII Grant PO1 HL43821.

Correspondence should be addressed to Leslie C. Timpe, Program of Excellence in Molecular Biology, Cardiovascular Research Institute, Box 0572, University of California, San Francisco, San Francisco, CA 94143-0572.

Copyright (C) 1994 Society for Neuroscience $0270-6474 / 94 / 141195-07 \$ 05.00 / 0$
}

to increased electrical excitability, however. Akins et al. (1990) showed that stimulation of a muscarinic receptor decreases the ability of rat neostriatal neurons to respond to excitatory synaptic input by shifting the activation curve of a voltage-activated $\mathrm{K}+$ channel; this shift increases the $\mathrm{K}^{+}$conductance at the resting membrane potential. The adrenergic, muscarinic, and TRH receptors mediating these responses are likely to be coupled to their effectors by heterotrimeric G-proteins. In this article we describe a novel example of $\mathrm{K}^{+}$channel modulation, by peptide growth factors, and experiments designed to determine which of several possible intracellular signaling pathways regulates the $\mathrm{K}^{+}$channel activity.

To examine the interaction between growth factor receptors and a voltage-activated $\mathrm{K}^{+}$channel, we coexpressed the cloned mouse type $\beta$ platelet-derived growth factor (PDGF) receptor (Yarden et al., 1986) and a cloned voltage-activated $\mathrm{K}^{+}$channel component, $\mathrm{K}_{\mathrm{v} 1.5}$ (Swanson et al., 1990), in Xenopus oocytes. Activation of the PDGF receptor caused the amplitude of the $\mathrm{K}_{\mathrm{v} 1.5}$ current to declinc, with a half-time of about $20 \mathrm{~min}$. Since PDGF is known to be mitogenic for glia (Noble et al., 1988; Raff et al., 1988; Richardson et al., 1988) and neurotrophic for neurons in vitro (Smits et al., 1991), the observation was intriguing as it suggested that PDGF may also be able to alter the pattern of a cell's electrical excitability. Furthermore, the modulation of $\mathrm{K}_{\mathrm{v} 1.5}$ by the PDGF receptor might occur by a novel mechanism. The receptor for PDGF is a transmembrane protein with an extracellular ligand binding domain and an intracellular tyrosine kinase domain. Modulation of $\mathrm{K}_{\mathrm{v} 1.5}$ channels by the PDGF receptor may result directly from phosphorylation of the channel on tyrosine, or indirectly through the activation of any of several intracellular signaling pathways. Proteins known to be phosphorylated on tyrosine by the activated PDGF receptor include the phosphatidyl inositol $3^{\prime}$ kinase (PI3-kinase), ras GTPase-activating protein (GAP), phospholipase C- $\gamma 1$ (PLC- $\gamma$ 1), and c-Src Nck (reviewed in Fantl et al., 1993); there may be other, unidentified, substrates. The possibility that phosphorylation of ras GAP may be required for modulation of this channel seemed particularly interesting, as ras GAP has been shown to interfere with activation of cardiac inward rectifier $\mathrm{K}^{+}$ channels by the muscarinic receptor (Martin et al., 1992).

The oocyte expression system is advantageous for studying the interactions between receptors and ion channels. An expression system provides the opportunity to use mutant receptors or channels to identify modulatory pathways. If channel phosphorylation is suspected as a mechanism for modulation, it may be possible to test the idea by labeling with ${ }^{32} \mathrm{PO}_{4}{ }^{2-}$, by site-specific mutagenesis of candidate acceptor sites or by proteolytic mapping techniques. In the experiments reported here 
Table 1. Effects of activation of several receptors on $K_{v 1.5}$ current amplitude

\begin{tabular}{lcl} 
Receptor & $\begin{array}{l}\text { Ligand } \\
\text { concentration }\end{array}$ & $\begin{array}{l}\text { Normalized } \mathrm{K}_{\mathrm{v} 1.5} \\
\text { current amplitude } \\
(30 \mathrm{~min})\end{array}$ \\
\hline PDGF & $2-5 \mathrm{nM}$ & $0.25 \pm 0.12 n=6$ \\
K602A PDGF & $2 \mathrm{nM}$ & $0.92 \pm 0.20 n=4$ \\
FGF & $3 \mathrm{nM}$ & $0.23 \pm 0.09 n=5$ \\
Y766F FGF & $3 \mathrm{nM}$ & $0.96 \pm 0.15 n=4$ \\
Thrombin $_{\text {Insulin }^{a}}$ & $10 \mathrm{nM}$ & $0.21 \pm 0.13 n=11$ \\
& $10 \mu \mathrm{M}$ & $0.82 \pm 0.08 n=4$
\end{tabular}

$\mathrm{K}_{1, j}$ currents were measured and normalized as in Figure 1. The fraction of the original current remaining $30 \mathrm{~min}$ after exposure to the ligand is provided, \pm SEM. a The insulin receptor is endogenous to the oocyte.

we describe the modulation of the $\mathrm{K}_{\mathrm{v} 1.5}$ current and identify the associated intracellular signaling pathway as a prelude to future experiments on the mechanism of $\mathrm{K}^{+}$channel modulation.

\section{Materials and Methods}

The $\mathrm{K}_{\mathrm{v} 1.5} \mathrm{cDNA}$, a gift from Dr. Leonard Kaczmarek, was originally named " $\mathrm{K}_{\mathrm{v}}$ " by Swanson et al. (1990). We follow the nomenclature of Chandy (1991). The $\mathrm{K}_{\mathrm{v} 1.5}$ sequence predicts a homolog of the Drosophila Shaker channel that is expressed in rat brain, heart, and the anterior pituitary (Swanson et al., 1990; Levitan et al., 1991). The cloning and sequences of the PDGF, fibroblast growth factor (FGF) (type 1), thrombin, and 5-HT ${ }_{1 c}$ receptors are described by Yarden et al. (1986), Lee et al. (1989), Vu ct al. (1991), and Julius et al. (1988), respectively; the mutant FGF receptor clone is a gift from Dr. K. Peters, and the thrombin and $5-\mathrm{HT}_{\mathrm{lc}}$ receptor cDNA clones are gifts from Drs. S. R. Coughlin and D. Julius. Capped RNA for $\mathrm{K}_{\mathrm{v}, \mathrm{s}}$ and for the four receptors was synthesized in runoff transcriptions using RNA polymerases (T3, T7) under standard conditions. After $2 \mathrm{hr}$ transcriptions the samples were extracted with $1: 1$ phenol:chloroform, precipitated in ethanol, and taken up in distilled water for injection into Xenopus oocytes.

Xenopus females (Nasco) were anesthetized with $0.15 \%$ tricaine, a small incision was made in the abdomen, and sections of the ovary were removed. Folliculated oocytes were injected with roughly $50 \mathrm{nl} /$ oocyte of specific RNA using a Drummond microdispenser. Approximately $10 \mathrm{ng}$ of $\mathrm{K}_{\mathrm{v} 1.5} \mathrm{RNA}$ and $25 \mathrm{ng}$ of receptor RNA were injected per oocyte. On the day after injection the follicular cells were softened by digestion with $4 \mathrm{mg} / \mathrm{ml}$ collagenase (Sigma type 1A) for $2-4 \mathrm{hr}$ at room temperature, to ease impalement with microelectrodes. Oocytes were studied on the second or third day after injection, when the responsiveness to PDGF or basic FGF was maximal.

A conventional two-microelectrode voltage-clamp circuit (Axon Instruments) was used; current was measured with a virtual ground circuit. Microelectrodes were filled with $3 \mathrm{M} \mathrm{KCl}$ and had tip resistances of $0.2-$ $1 \mathrm{M} \Omega$. Series resistance was determined by injecting a current step (under current-clamp conditions) and measuring the initial jump in potential with a second intracellular microelectrode. Seventy to ninety percent of the series resistance was compensated by scaling the current signal and adding it to the voltage command. The current and voltage signals were digitized at 12-bit resolution, written to a hard disk, and analyzed using pCLAMP version 5.5 (Axon Instruments). The current and voltage traces were sampled at $10^{4}, 5 \times 10^{3}$, or $2 \times 10^{3} \mathrm{~Hz}$, and the current traces were filtered $(-3 \mathrm{~dB})$ at $10^{3}, 5 \times 10^{2}$, or $2 \times 10^{2} \mathrm{~Hz}$, respectively, using an 8-pole Bessel filter (Frequency Devices). The current traces displayed in the figures and used to calculate entries in Table 1 were corrected for leak current. Linear leak current was estimated by voltage steps from the holding potential to more negative potentials ( $-P / 4$ procedure). In the Results and in Table 1 average values of normalized current amplitudes are given at specified times after introducing a ligand into the chamber. In some cases there was no measurement within $1 \mathrm{~min}$ of the time indicated; linear interpolations between the two nearest measurements were then used.

The oocytes were studied at room temperature in a chamber containing about $250 \mu$ lof saline. In most experiments the chamber was perfused at $2 \mathrm{ml} / \mathrm{min}$, and growth factors, thrombin, or 5-HT were applied via the perfusion system for 5-10 min. In a few experiments the ligand was maintained in the saline for the duration of the experiment, 30 min or more. In these experiments with a longer exposure to ligand there was no detectable difference in the magnitude or rate of onset of the response. For experiments with arachidonic acid or prostaglandins, the bath perfusion was stopped and the compounds applied directly into the chamber to bypass the reservoir and perfusion lines. For inositol trisphosphate $\left(\mathrm{IP}_{3}\right)$ injections, the $\mathrm{IP}_{3}$ (Sigma) was taken up in $3 \mathrm{M} \mathrm{KCl}$ at $1 \mathrm{~mm}$ and loaded into the micropipette by backfilling. The IP ${ }_{3}$ (current-passing) electrode was inserted into the oocyte's animal pole. Within a few minutes of impaling the oocyte and clamping at the holding potential of $80 \mathrm{mV}$, the holding current and the $\mathrm{Ca}^{\gamma+}$-activated $\mathrm{Cl}^{-}$current began to increase; these responses indicated that sufficient $\mathrm{IP}_{3}$ had entered the cell to trigger $\mathrm{Ca}^{2+}$ release.

The $\mathrm{Ca}^{2+}$-activated $\mathrm{Cl}^{-}$current that is endogenous to the oocyte can interfere with measurement of the $\mathrm{K}_{v 1.5}$ current. Current separation was achieved by expressing the $\mathrm{K}_{\mathrm{v} 1.5}$ channel at $1-10 \mu \mathrm{A}$, when measured in the steady state at $40 \mathrm{mV}$. This current level is larger than the background current, which varies from undetectable to $0.5 \mu \mathrm{A}$ when measured at $40 \mathrm{mV}$ in unstimulated oocytes. Furthermore, activation of the $\mathrm{Ca}^{2+}$-dependent $\mathrm{Cl}^{-}$current is slow, and is not complete when the amplitude of the $\mathrm{K}_{\mathrm{v} 1.5}$ current is measured $400 \mathrm{msec}$ into the voltage pulse. When oocytes express receptors for PDGF or FGF, stimulation with the growth factor induces a transient increase in the $\mathrm{Ca}^{2+}$-activated $\mathrm{Cl}^{-}$current (see Fig. $3 B$ ). The induced current typically subsides by 30 min, when the measurements reported in Table 1 were taken. In preliminary experiments we tested the usefulness of a low- $\mathrm{Cl}^{-}$saline $(13$ $\mathrm{mM} \mathrm{Cl}^{-}$, substituting with $\mathrm{SO}_{4}{ }^{2-}$ ) for reducing the level of background current. The amplitude of the endogenous current was reduced in this saline, but the recordings were less stable than in the standard saline.

The standard saline solution contained (in $\mathrm{mm}$ ) $88 \mathrm{NaCl}, 1 \mathrm{KCl}, 2.4$ $\mathrm{NaHCO}_{3}, 0.82 \mathrm{MgSO}_{4}, 0.7 \mathrm{CaCl}_{2}$, and 10 HEPES, at pH 7. Prostaglandins $\mathrm{E}_{1}\left(\mathrm{PGE}_{1}\right)$ and $\mathrm{E}_{2}\left(\mathrm{PGE}_{2}\right)$, and arachidonic acid (Sigma) were taken up in absolute ethanol, aliquoted, and stored under nitrogen at $-20^{\circ}$. The prostaglandins and arachidonic acid were diluted in saline immediately before use. Human thrombin was a gift from Dr. J. W. Fenton II. 5-HT (Sigma) was taken up in distilled water and stored at $-80^{\circ}$. Aliquots were thawed and diluted to $10^{-7} \mathrm{~mm}$ shortly before use. Phorbol 12-myristate 13-acetate (PMA) was stored at $1 \mathrm{mg} / \mathrm{ml}$ in dimethyl sulfoxide and diluted before use.

${ }^{35}$ S labeling and immunoprecipitation. Oocytes (40 per lane shown in Fig. 3) were injected with wild-type or mutant FGF receptor RNA and incubated in $1 \mathrm{mCi} / \mathrm{ml}^{35} \mathrm{~S}$-methionine and ${ }^{35} \mathrm{~S}$-cysteine (Translabel, ICN) and frog saline. After $2 \mathrm{~d}$ of incubation the oocytes were washed gently in frog saline and lysed in a buffer containing $50 \mathrm{~mm}$ Tris $(\mathrm{pH}$ $7.8), 150 \mathrm{mM} \mathrm{NaCl}, 1 \mathrm{~mm}$ EDTA, $0.5 \% \mathrm{NP} 40$, and $10 \%$ glycerol. Phenylmethylsulfonyl fluoride ( $2 \mathrm{mM})$, sodium vanadate $(2 \mathrm{~mm})$, and leupeptin $(1 \mu \mathrm{g} / \mathrm{ml})$ were added immediately prior to lysis. The lysate was agitated gently for $20 \mathrm{~min}$ at $4^{\circ}$ and centrifuged, and the aqueous phase was separated from lipid and insoluble material. A rabbit polyclonal antibody raised to an epitope in the juxtamembrane portion of the FGF receptor was used at a dilution of 1:1000 for immunoprecipitation of the receptor (Peters et al., 1992). The samples were incubated overnight at $4^{\circ}$ with protein $\Lambda$, under denaturing conditions in the presence of $0.1 \%$ sodium dodecyl sulfate and $0.5 \%$ sodium deoxycholate. The immunoprecipitates were washed as described previously (Fantl et al., 1992). The samples were subjected to SDS-PAGE. After fixing, the gel was soaked in Amplify for $30 \mathrm{~min}$. The gel was dried and autoradiography carried out using Kodak XAR film.

\section{Results}

Figure $1 A$ illustrates the modulatory action of the activated PDGF receptor on the $\mathrm{K}_{\mathrm{v} 1.5}$ current. The PDGF receptor and the $\mathrm{K}^{+}$channel were coexpressed in Xenopus oocytes; $\mathrm{K}^{+}$current was measured under voltage-clamp conditions using two intracellular electrodes. Thirty minutes after stimulation with PDGF (2 nM), the current amplitude had declined to about $30 \%$ of its initial value. Figure $1 B$ charts the time course of this effect. After stimulation with PDGF (solid symbols) there was a delay of a few minutes before any change in $\mathrm{K}^{+}$current amplitude was detected. When the $\mathrm{K}^{+}$current began to decline the rate was slow, requiring 15-20 min to reach one-half the initial level. 
If the oocytes were not stimulated with PDGF (open symbols), the $K_{v 1.5}$ currents could be recorded without significant decline for at least $45 \mathrm{~min}$. During this time there was no indication of current recovery in oocytes exposed to PDGF. In a few experiments lasting an hour or more the current amplitude began to recover, but much more slowly than the initial rate of decline. Modulation of the $\mathrm{K}_{\mathrm{v} 1.5}$ channel requires tyrosine kinase activity, as a mutant receptor defective in this activity has little effect on the $\mathrm{K}_{\mathrm{v} 1.5}$ current (Table 1). This mutation (alanine replaces lysine at position 602) alters a putative ATP binding sitc and has becn shown to have no PDGF-sensitive tyrosine kinase activity (Escobedo et al., 1988).

During the first few minutes after receptor stimulation, the $\mathrm{Ca}^{2+}$-activated $\mathrm{Cl}^{-}$current, which is endogenous to the oocyte (Barrish, 1983), increased in amplitude and then spontaneously declined (see Fig. $3 B$ ). The amplitude of this $\mathrm{Cl}^{-}$current reflects the cyloplasmic $\mathrm{Ca}^{2+}$ concentration, and its increase probably results from $P D G F$ receptor activation, increased PLC activity, production of $\mathrm{IP}_{3}$, and the release of $\mathrm{Ca}^{2+}$ from intracellular stores. Activation of the receptors for PDGF caused a transient increase in the current required to hold the membrane at -80 $\mathrm{mV}$; this increase paralleled the increase in the $\mathrm{Ca}^{2+}$-activated $\mathrm{Cl}^{-}$current. After $30 \mathrm{~min}$ the holding current had usually returned to its initial value. The decline in $\mathrm{K}_{\mathrm{v} 1.5}$ current was not associated with an irreversible increase in the holding current.

The decline in $\mathrm{K}_{\mathrm{v} t . \mathrm{s}}$ current amplitude might be due to any of several causes, including a change in reversal potential, a shift in voltage sensitivity, or a change in gating kinetics such that the open probability is reduced at steady state. In four experiments the reversal potential was measured before and after stimulation with PDGF. Before PDGF the tail current reversed at $-92 \pm 5 \mathrm{mV} ; 0.5 \mathrm{hr}$ after stimulation with PDGF, when the currents had declined to an average of $27 \%$ of their control levels, the reversal potential was $-84 \pm 5 \mathrm{mV}( \pm \mathrm{SD})$. These differences are not significant at the $5 \%$ confidence level (twosample $t$ test).

The decline in the amplitude of the $K_{v 1.5}$ current is not associated with a large change in the kinetics or voltage sensitivity of the channels. Figure $2 A$ demonstrates that there is little if any alteration in the activation kinetics even after the current amplitude has declined about 3.5-fold; the reduced currents can be scaled to superimpose on the control currents. Figure $2 B$ shows the effect of current modulation on the steady state activation curve. The extent of activation in the steady state was determined from the relative amplitudes of tail currents $40 \mathrm{~min}$ after receptor activation. Activation data from each of four oocytes were fit to the Boltzmann equation using nonlinear regression. The average values for the midpoints before and 40 min after cxposure to PDGF were $-5 \pm 1.4( \pm \mathrm{SD})$ and $-2 \pm$ $3.7 \mathrm{mV}$, respectively, which do not differ significantly at the $5 \%$ confidence level according to the paired $t$ test. The slope factors before and $40 \mathrm{~min}$ after PDGF stimulation were $8 \pm 0.67$ and $10 \pm 0.70 \mathrm{mV}$, values that differ significantly at the $5 \%$ confidence level. This reduction in voltage sensitivity is small, and, if real, should have less physiological importance than the large reduction in current amplitude. These results are compatible with a mechanism in which receptor activation reduces the number of $\mathrm{K}^{+}$channels that are available for opening, but the findings do not rule out the possibilities of either a very rapid block or a reduction in unitary conductance.

How is the activity of the $\mathrm{K}_{\mathrm{v} 1.5}$ channel regulated by the PDGF receptor? One possibility is that the activated receptor phos-
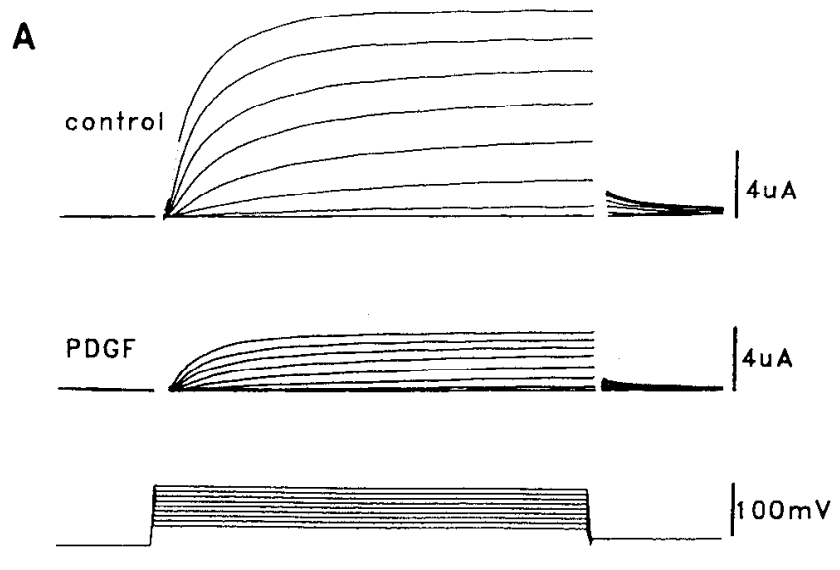

$\underline{20 \mathrm{~ms}}$

B

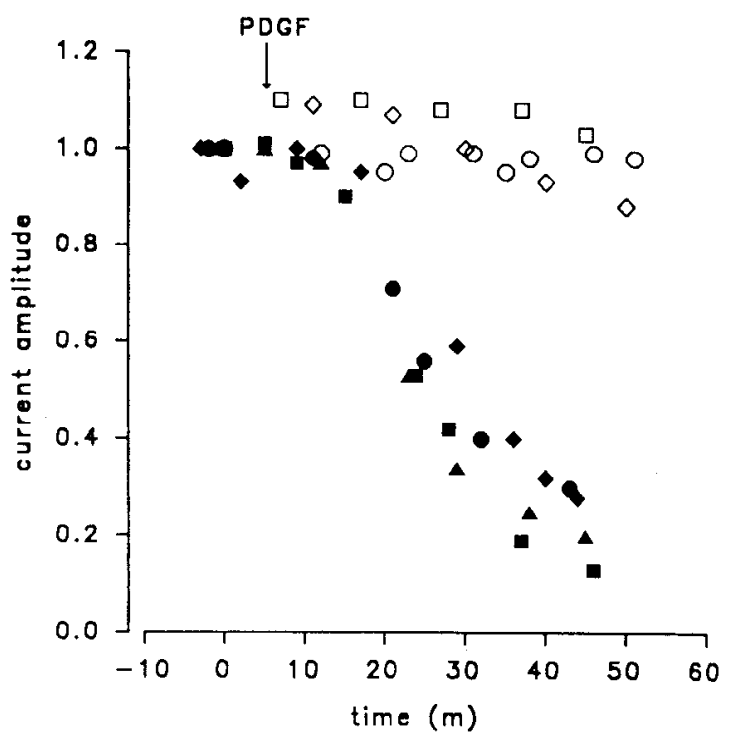

Figure 1. Stimulation of the PDGF receptor causes a slow decline in $\mathrm{K}_{\mathrm{v} 1.5}$ current amplitude. $A, \mathrm{~K}_{\mathrm{v} 1.5}$ current measured in an oocyte that had been injected with specific RNA for the $\mathrm{K}^{+}$channel and for the PDGF receptor. The upper set of current traces was taken before, and the lower set 42 min after, perfusion of the bath with PDGF ( $2 \mathrm{nM})$. The membrane was stepped from $-80 \mathrm{mV}$ to positive potentials from -40 to $40 \mathrm{mV}$ in $10 \mathrm{mV}$ increments, and then returned to $-60 \mathrm{mV}$. $B$, The time course of the current decline. The $\mathrm{K}^{+}$current level was measured $100 \mathrm{msec}$ after the membrane had been stepped to $40 \mathrm{mV}$, then normalized to the measurement made at $t=0 \mathrm{~min}$, before exposure to PDGF. Each symbol corresponds to one oocyte. The solid symbols identify oocytes exposed to PDGF (2-5 nM) at the arrow; open symbols specify oocytes that were also injected with $\mathrm{K}_{\mathrm{v} 1.5}$ and PDGF receptor RNA but not stimulated with PDGF.

phorylates the channel on tyrosine, making it less likely or unable to open. Most of the known substrates of the PDGF receptor contain Src homology domains (SH2 domains), which form high-affinity binding sites for the activated receptor (Koch et al., 1991). A comparison of the predicted amino acid sequence of $\mathrm{K}_{\mathrm{v} 1.5}$ to the $\mathrm{SH} 2$ domain sequences from $\mathrm{Src}$ tyrosine kinase, PLC- $\gamma 1$ (domain 1), and ras GAP (amino SH2 domain) in the Protein Identification Resource (PIR) database showed no significant homology. Furthermore, the delay between receptor 
A

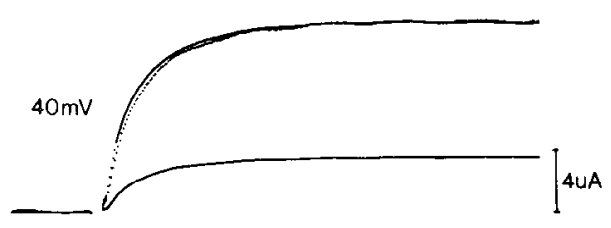

$-10 \mathrm{mV}$

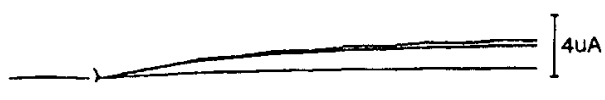

B

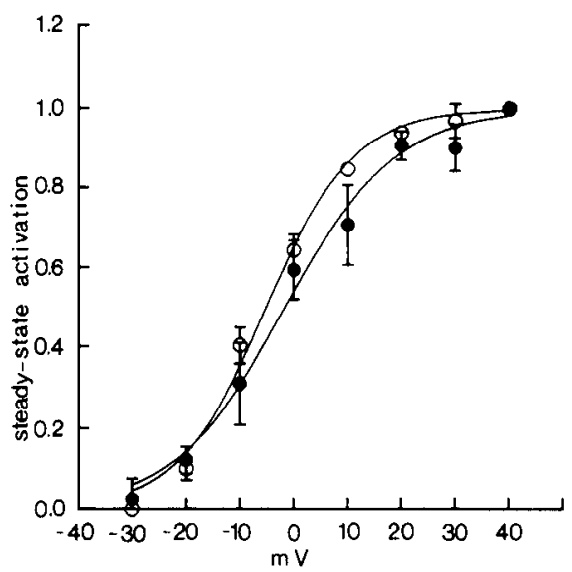

$\overline{20 \mathrm{~ms}}$

Figure 2. Modulation of the $\mathrm{K}_{\mathrm{v} 15}$ current by the PDGF receptor has little effect on activation kinetics or voltage sensitivity. The oocytes expressed both $\mathrm{K}_{\mathrm{v} \text { l.s }}$ and PDGF receptor RNA. $A$, The $\mathrm{K}_{\mathrm{v} 1.5}$ current elicited by a potential step from $-80 \mathrm{mV}$ to $40 \mathrm{mV}$ is shown (larger current), as is the smaller current evoked by the same command 39 min after stimulation with $5 \mathrm{~nm}$ PDGF. When the smaller current is scaled by a factor of 3.45 (dotted line), its activation rate nearly superimposes with that of the control current. The lower set of traces shows a similar experiment, with steps to $-10 \mathrm{mV}$. The scaling factor was also $3.45 . B$. Steady state activation before (open circles) and after (solid circles) modulation of $\mathrm{K}_{\mathrm{v} . .5}$ by the PDGF receptor. The membrane potential was stepped from $-80 \mathrm{mV}$ to conditioning potentials between -30 and $40 \mathrm{mV}$ for $100 \mathrm{msec}$, and then returned to $-60 \mathrm{mV}$ for measuring the amplitudes of the current tails (see Fig. 1). Tail current amplitudes were normalized to the value associated with $40 \mathrm{mV}$ conditioning steps, averaged ( $n=4 ; \pm S D$ where larger than the symbol), and plotted against the command potential. The measurements for the solidd symbols were made at an average of $41 \mathrm{~min}$ (range, $39-42 \mathrm{~min}$ ) after exposure to 2-5 nM PDGF. The average reduction in current amplitude was to $20 \%$ of the initial value (range, 13-29\%). The smooth curves are Boltzmann functions with midpoints of -5 and $-2 \mathrm{mV}$ and slope factors of 8 and $10 \mathrm{mV}$ for the data taken before and after PDGF stimulation, respectively.

activation and the beginning of the decline in current amplitude suggests that there may be one or more intervening steps.

The PDGF receptor phosphorylates several proteins including PLC- $\gamma 1$, the p85 component of the PI3-kinase, GAP, Src tyrosine kinase, and Nck. We tested with coinjection experiments three other receptors known to increase PLC activity: the human type $1 \mathrm{FGF}$, human thrombin, and rat $5-\mathrm{HT}_{\mathrm{Ic}}$ receptors (Julius et al., 1988; Lee et. al., 1989; Vu et al., 1991). The FGF and thrombin receptors each induced a slow decline in $\mathrm{K}_{\mathrm{v} 1.5}$ current amplitude, following a delay of a few minutes (Table 1). The receptor for 5-HT induced a decline in $\mathrm{K}_{\mathrm{v} 1.5}$ current even in the absence of 5-HT. This decrease was not seen in oocytes from the same donor frogs that were injected with cRNA for other receptors. In two experiments in which the amplitude of the $\mathrm{K}_{\mathrm{v} 1.5}$ current was fairly stable, $10^{-7} \mathrm{M} 5$ - HT hastened the current decline. Increasing the activity of PLC is the only effect known to be shared by these receptors, suggesting that perhaps the regulation of $\mathrm{K}_{\mathrm{v1.5}}$ current requires the activation of this enzyme. The receptors for thrombin and 5-HT are probably coupled to PLC by heterotrimeric G-proteins rather than by tyrosine phosphorylation. In cows, for example, a heterotrimeric G-protein activates the $\beta 1$ isoform of PLC, but not the $\gamma 1$ isoform, which is activated by receptor tyrosine kinases (Taylor et al., 1991). In toad oocytes the thrombin and 5-HT ${ }_{1 \mathrm{c}}$ receptors may therefore activate a variant of PLC different from that activated by the PDGF and FGF receptors.

The receptors for PDGF and FGF are receptor tyrosine kinases that have overall structural similarity and that are thought to have a similar mechanism of activation (Cantley et al., 1991; Fantl et al., 1993). The Xenopus oocyte expresses an endogenous insulin receptor that is also a receptor tyrosine kinase, but which is a member of a different family and which in other tissues is unable to activate PLC- $\gamma$ 1. Stimulation of the insulin receptor has little effect on the amplitude of the $K_{\mathrm{v} 1.5}$ current (Table 1). Stimulating cells with insulin increases PI3-kinase activity, perhaps by phosphorylating the protein directly (Roth et al., 1992). Thus modulation of the $\mathrm{K}_{\mathrm{v} 1.5}$ current by the PDGF receptor probably does not require activation of the PI3-kinase.

Recent work on the PDGF and FGF receptors indicates that different substrates bind these receptors at different sites (Fantl et al., 1992), now raising the possibility of creating mutant receptors that disrupt phosphorylation of individual substrates selectively. Peters et al. (1992) and Mohammadi et al. (1992) report that substitution of phenylalanine for tyrosine at position 766 in the human FGF receptor creates a receptor that, when expressed in rat I.6 cells, does not associate with or phosphorylate PLC- $\gamma 1$. Consequently there is no hydrolysis of phosphatidylinositol. The mutant receptor is mitogenic in these cells, however, and does phosphorylate both itself and other substrates seen with the wild-type receptor. In Xenopus oocytes the mutant FGF receptor protein is expressed as efficiently as the wild type (Fig. $3 A$ ); both precursor and processed (glycosylated) forms are seen. The mutant receptor, however, is not able to activate the $\mathrm{Ca}^{2+}$-activated $\mathrm{Cl}^{-}$current (Fig. 3B). This is the expected phenotype if the mutant receptor does not increase hydrolysis of phosphatidylinositol 4,5-bis-phosphate $\left(\mathrm{PIP}_{2}\right)$. In coexpression experiments the mutant FGF receptor is not able to modulate $K_{\mathrm{v} 1.5}$ current amplitude (Fig. 4, Table 1). To the extent that the single residue substitution disrupts activation of PLC- $\gamma$ I specifically, this result provides strong evidence that increased PLC activity is required for the reduction in $\mathrm{K}_{\mathrm{v} 1.5}$ current amplitude.

PLC hydrolyzes PIP to $\mathrm{IP}_{3}$ and to diacylglycerol (DAG). One possible signaling mechanism is through the production of arachidonic acid by the action of DAG lipase on DAG, leading to the formation of messengers such as leukotrienes, prosta- 
A

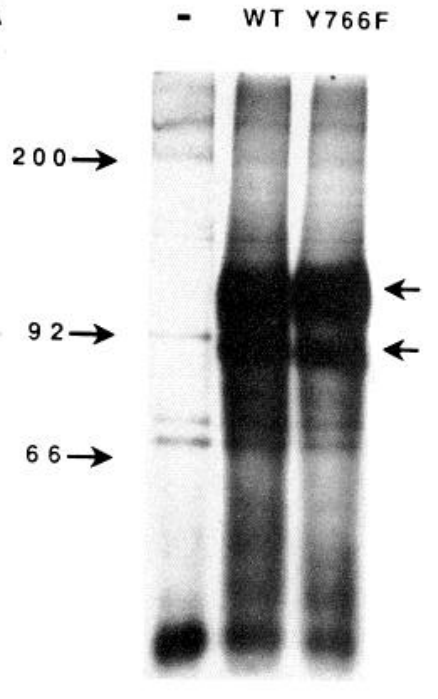

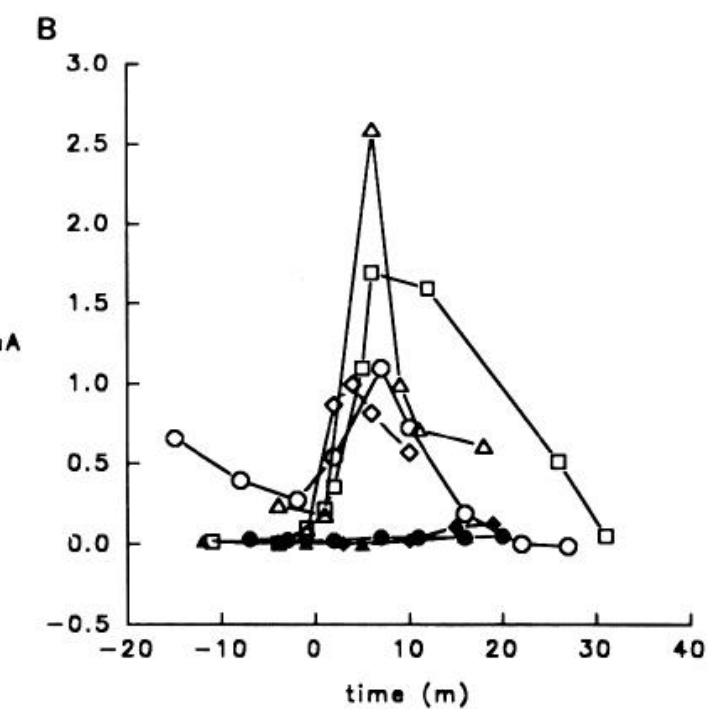

Figure 3. The $\mathrm{Y} 766 \mathrm{~F}$ mutant receptor is expressed in Xenopus oocytes, but does not trigger $\mathrm{Ca}^{2+}$ release. $A$, The mutant and wild-type FGF receptors are expressed at similar levels in Xenopus oocytes. Forty oocytes were injected with wild-type or mutant RNA, or not injected, and incubated in ${ }^{35} \mathrm{~S}$-methionine. Labeled protein was immunoprecipitated with an anti-FGF receptor antiserum, then subjected to SDS-PAGE and autoradiography. The FGF precursor and processed forms (lower and upper arrows) are present at similar levels in oocytes injected with mutant or wildtype RNA. Molecular weight $(\mathrm{kDa})$ markers are shown on the left. B, Amplitude of the endogenous $\mathrm{Ca}^{2+}$-activated $\mathrm{Cl}^{-}$current $(\mu \mathrm{A})$ in oocytes injected with wild-type FGF receptor RNA (open symbols) and mutant receptor RNA (solid symbols). Each symbol corresponds to one oocyte. At $0 \mathrm{~min}$ the oocytes were stimulated with $3 \mathrm{~nm}$ basic FGF. The $\mathrm{Cl}^{-}$current was measured in the steady state, $0.5 \mathrm{sec}$ after a step from $-80 \mathrm{mV}$ to $40 \mathrm{mV}$. glandins, or thromboxanes. To test for a role for arachidonic acid metabolites in the modulation of $\mathrm{K}_{\mathrm{v} 1.5}$ current, arachidonic acid (70-100 $\mu \mathrm{M})$ was applied to oocytes expressing $\mathrm{K}_{\mathrm{v} 1.5}$ in four experiments. After 2 min the average $\mathrm{K}_{\mathrm{v} 1.5}$ current amplitude was $95 \%$ of the control value; after 10 min the current was still $95 \%$ of the control. In experiments with $\mathrm{PGE}_{1}(6-30 \mu \mathrm{M})$ the current was $111 \%(n=3)$ of the control after $2 \mathrm{~min}, 88 \%(n=$ 4) after $10 \mathrm{~min}$, and $85 \%(n=2)$ after $30 \mathrm{~min}$. In a single experiment with $\mathrm{PGE}_{2}(3 \mu \mathrm{M})$ the current was $132 \%$ of the initial level after $2 \mathrm{~min}$. Two minutes are sufficient to detect the activation of cardiac muscarinic $\mathrm{K}^{+}$channels by arachidonic acid in experiments with cell-attached patch electrodes (Kim et al., 1989). Lacking a positive control it is difficult to judge the significance of the measurements at 10 or $30 \mathrm{~min}$, as arachidonic acid and prostaglandins are quite labile in aqueous solutions at room temperature. Nevertheless the results do not support the hypothesis that arachidonic acid metabolites, particularly $\mathrm{PGE}_{1}$, mediate the regulation of $\mathrm{K}_{\mathrm{v} 1.5}$ channels.

If PLC activity is required for the modulation of $\mathrm{K}_{\mathrm{v} 1.5}$ current, it should be possible to mimic the effect by simultaneously injecting oocytes with $\mathrm{IP}_{3}$ and superfusing them with a DAG analog. $\mathrm{IP}_{3}$ was injected iontophoretically using the currentpassing microelectrode; at the same time the experimental chamber was perfused with 10 nM PMA. In seven experiments the average current was reduced to $34 \%$ at $20 \mathrm{~min}$, with little variation among the oocytes (Fig. 5, top). The reduction in current amplitude appears to be slightly faster than the receptormediated effect, with a half-time of about $12 \mathrm{~min}$. Neither $\mathrm{IP}_{3}$ nor PMA alone was as effective in modulating the current amplitude. In a series of nine experiments $\mathrm{IP}_{3}$ injections caused a reduction in $\mathrm{K}_{\mathrm{v} 1.5}$ current to $77 \%$ of the initial level by $30 \mathrm{~min}$ (Fig. 5, middle); this is less than the reduction to $25 \%$ seen with PDGF receptor. The responses to $\mathrm{IP}_{3}$ injection were more variable than the responses to receptor stimulation or simultaneous exposure to both messengers. The nine experiments included oocytes in which the current amplitude increased or did not respond to $\mathrm{IP}_{3}$, and oocytes in which the decrease was nearly as rapid as the receptor-mediated responses. In another set of experiments seven oocytes were exposed to 10 nM PMA, but no $\mathrm{IP}_{3}$ (Fig. 5, bottom). After 30 min the currents were reduced to $59 \%$ of the initial level, with significant variation in the individual responses as in the $\mathrm{IP}_{3}$ experiments. While these results support the role of PLC in receptor-mediated modulation, they do not distinguish clearly between a mechanism that depends on the activation of protein kinase $\mathrm{C}$, or one that requires elevated intracellular $\mathrm{Ca}^{2+}$ for channel modulation. Both mechanisms have been proposed for the modulation of other voltageactivated $\mathrm{K}^{+}$channels by 5 -HT receptors (Hoger et al., 1991; Kavanaugh et al., 1991; Attali et al., 1992).

\section{Discussion}

These experiments reveal some novel aspects of ion channel modulation. This is the first report of modulation of a voltageactivated $\mathrm{K}^{+}$channel by receptors for peptide growth factors.

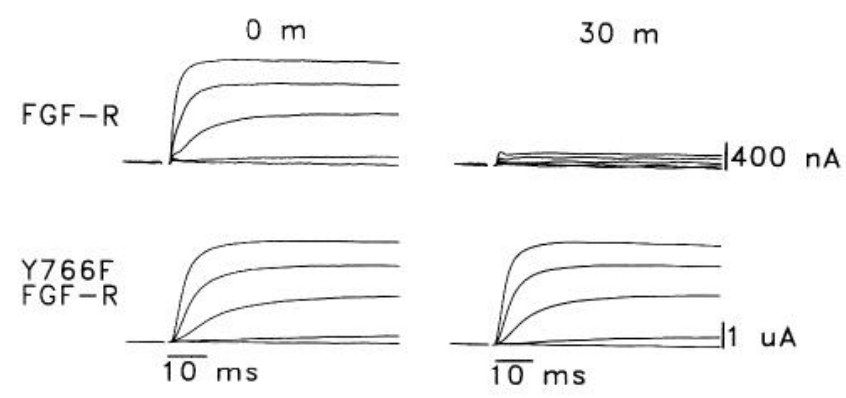

Figure 4. $\mathrm{K}_{\mathrm{v} 1.5}$ current is regulated by the wild-type $\mathrm{FGF}$ receptor, but not by the $\mathrm{Y} 766 \mathrm{~F}$ mutant $\mathrm{FGF}$ receptor. The upper row of traces shows control $\mathrm{K}_{\mathrm{v} 1.5}$ current (left) and the current reduction $30 \mathrm{~min}$ after stimulating the wild-type FGF receptor with $3 \mathrm{~nm}$ basic FGF. The lower row demonstrates the result of a similar experiment on an oocyte expressing the $\mathrm{Y} 766 \mathrm{~F}$ mutant FGF receptor. The voltage was stepped from the holding potential $(-80 \mathrm{mV})$ to test potentials between -40 and $40 \mathrm{mV}$ in $20 \mathrm{mV}$ increments. 


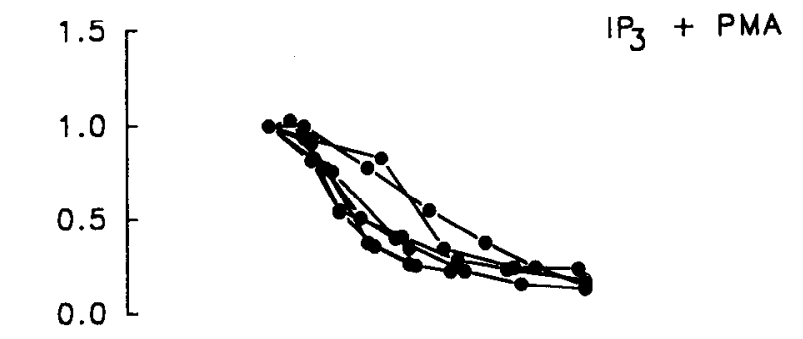

rapid, means by which reccptors for PDGF and FGF may altcr the pattern of a cell's electrical excitability. The one example of a similar phenomenon that we are aware of was reported by Puro and Mano (1991), who found that basic FGF induces an increase in the amplitude of a voltage-sensitive $\mathrm{Ca}^{2+}$ current in human retinal glia over $15-20 \mathrm{~min}$.

In non-neuronal cells, in contrast, there are several known examples of peptide growth factors altering ionic conductances within minutes of application. PDGF activates a channel selective for monovalent cations in a mouse fibroblast line, LMTK

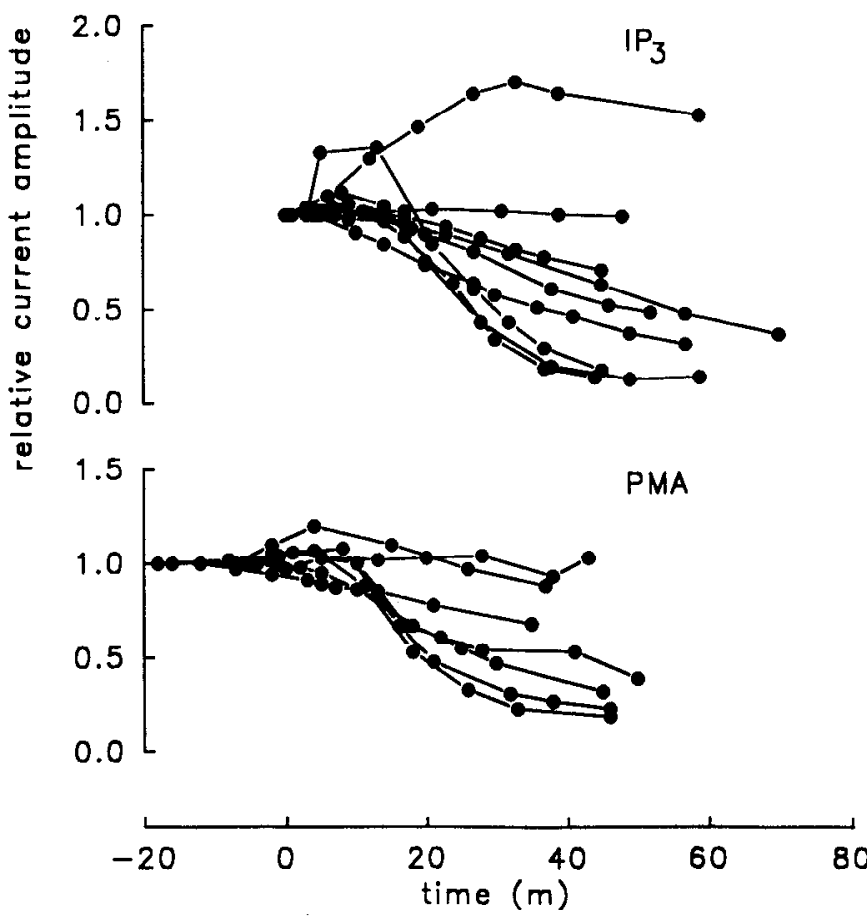
(Frace and Gargus, 1989). In two human carcinoma lines, A431 and $\mathrm{KB}$, stimulation of the epidermal growth factor receptor hyperpolarizes the membrane potential by opening a $\mathrm{Ca}^{2+}-\mathrm{ac}-$ tivated $\mathrm{K}^{+}$channel (Pandiella et al., 1989). Human retinal glial cells express a $\mathrm{Ca}^{2+}$-activated $\mathrm{Ca}^{2+}$ channel that is insensitive to voltage; exposure to basic FGF increases the open probability of the channel (Puro, 1991). Pandiella et al. (1989) and Puro (1991) propose that intracellular $\mathrm{Ca}^{2+}$ may couple receptor activation directly to these $\mathrm{Ca}^{2+}$-activated $\mathrm{K}^{+}$and $\mathrm{Ca}^{2+}$ channels.

What would be the physiological consequence of reduced voltage-activated $\mathrm{K}^{+}$current in an electrically excitable cell? Modulation of the $\mathrm{K}^{+}$current would be expected to prolong the action potential, and perhaps to lower its threshold. An example is known in GH3 cells, a pituitary line, where TRII prolongs the action potential in spontaneously active cells by decreasing the amplitude of a voltage-activated $\mathrm{K}^{+}$current (Dubinsky and Oxford, 1985). As the TRH receptor is coupled to PLC (Gershengorn, 1989), this phenomenon is similar to the modulation of $\mathrm{K}_{\mathrm{v} 1.5}$ by growth factor and neurotransmitter receptors in oocytes. Levitan et al. (1991) have reported that the $\mathrm{K}_{\mathrm{v} 1.5}$ mRNA is expressed in $\mathrm{GH} 3$ cells and in the anterior pituitary, raising the possibility that the voltage-activated $\mathrm{K}^{+}$channels studied by Dubinsky and Oxford are $\mathrm{K}_{\mathrm{v} 1.5}$ homomultimers, or perhaps heteromultimers with one or more $\mathrm{K}_{\mathrm{v} 1.5}$ subunits.

Several recent reports have reported modulatory effects be-

Figure 5. Intracellular iontophoresis of $\mathrm{IP}_{3}$ and simultaneous bath perfusion of PMA reduce $\mathrm{K}_{\mathrm{v} 1.5}$ current amplitude. The oocytes expressed $\mathrm{K}_{\mathrm{v} 1,5}$ channels, but had not been injected with receptor $\mathrm{RNA}$. The upper panel shows the results of joint $\mathrm{IP}_{3}$ iontophoresis and exposure to 10 nM PMA in seven oocytes. The rate of decline of the $\mathrm{K}_{\mathrm{v} 1.5}$ current was similar to that found with PDGF and FGF receptor activation. The middle panel displays the results of nine experiments in which $\mathrm{IP}_{3}$ was iontophoresed from the current electrode into the oocyte. The lower panel shows the results of seven experiments in which the bath was perfused with 10 nM PMA at time zero, and PMA was maintained in the bath for the duration of the experiment. In the upper and middle panels time zero corresponds to current measurements taken within one minute of penetrating the oocyte and clamping to the holding potential.

The reduction in amplitude of the $\mathrm{K}_{\mathrm{v} 1.5}$ current requires the activation of PLC, and occurs rapidly compared to the time course of neurotrophic effects or to changes in electrical excitability that might be caused by altered gene transcription. For example, growth factors alter the expression of ion channels in PC12 cells, a clonal line derived from a pheochromocytoma. Cells cultured in medium supplemented with NGF or FGF increase the expression of voltage-activated $\mathrm{Na}^{+}$channels in parallel with the outgrowth of neurites, compared with cultures not exposed to NGF or FGF (Garber et al., 1989; Pollock et al., 1990). The increase in $\mathrm{Na}^{+}$channel density is associated with higher levels of $\mathrm{Na}^{+}$channel mRNA following NGF treatment (Mandel et al., 1988). In these studies the effects of NGF or FGF were assessed after $2 \mathrm{~d}$ to several weeks in culture, rather than immediately after application of the growth factor. In contrast, the experiments reported here identify an alternative, more channels $\left(\mathrm{K}_{\mathrm{v1.1}}, \mathrm{K}_{\mathrm{v1.2}}, \mathrm{K}_{\mathrm{v1.3}}\right)$ expressed in Xenopus oocytes, as found here with $\mathrm{K}_{\mathrm{v} 1.5}$ (Hoger et al., 1991; Kavanaugh et al., 1991; Attali et al., 1992). The mechanism of these effects resembles that described in this articlc, as the $5-\mathrm{HT}_{1 \mathrm{c}}$ and $5-\mathrm{HT}_{2}$ receptors are known to be coupled to PLC (Julius, 1991). Furthermore, the kinetics are comparable: in each case $\mathrm{K}^{+}$current amplitude reaches nadir roughly $20 \mathrm{~min}$ after receptor stimulation, and then recovers slowly, if at all. These three groups differ, however, on whether the $\mathrm{K}^{+}$currents are sensitive to analogs of DAG and to phorbol esters. Hoger et al. (1991) and Kavanaugh et al. (1991) report that PMA and phorbol dibutyrate have no effect on the $\mathrm{K}^{+}$currents, whereas Attali et al. (1992) find that oleoylacetylglycerol and PMA both cause the current to decline. Therefore, the mechanisms of action on these $\mathrm{K}^{+}$channel variants may not be identical to each other or to the phenomenon described here.

There are several examples of receptors for PDGF or FGF and $\mathrm{K}^{+}$channels being expressed in the same cells, providing an opportunity for the phenomenon that we have studied in oocytes to occur in vivo. Progenitor cells for oligodendrocytes and type 2 astrocytes, O-2A cells, express receptors for PDGF and FGF, and also voltage-activated $\mathrm{K}^{+}$channels (Bevan et al., 1987). PDGF is neurotrophic for adult rat neurons in primary culture (Smits et al., 1991); likewise, FGF is neurotrophic and neuritotrophic for granule cells and hippocampal neurons in culture (Walicke et al., 1986; Hatten et al., 1988). It would be 
of interest to look for rapid effects of PDGF or FGF on the electrical excitability of glia or neurons.

\section{References}

Aghajanian GK (1985) Modulation of a transient outward current in serotonergic neurones by alpha 1-adrenoceptors. Nature 31 5:501-502.

Akins PT, Surmeier DI, Kitai ST (1990) Muscarinic modulation of a transient $\mathrm{K}^{+}$conductance in rat neostriatal neurons. Nature 344:240242

Attali B, Honore E, Florian L, Lazdunski M, Barhanin J (1992) Regulation of a major cloned voltage-gated $\mathrm{K}^{+}$channel from human $\mathrm{T}$ lymphocytes. FEBS Lett 303:229-232.

Barrish ME (1983) A transient calcium-dependent chloride current in the immature Xenopus oocyte. J Physiol (Lond) 342:309-325.

Bevan S, Lindsey RM, Perkins MN, Raff MC (1987) Voltage-gated ionic channels in rat cultured astrocytes, reactive astrocytes and an astrocyte-oligodendrocyte progenitor cell. J Physiol (Paris) 82:327335.

Cantley LC, Auger KR, Carpenter C, Duckworth B, Graziani A, Kapeller R, Soltoff S (1991) Oncogenes and signal transduction. Cell 64:281-302.

Chandy G (1991) Simplified gene nomenclature. Nature 352:26.

Dubinsky JM, Oxford GS (1985) Dual modulation of K channels by thyrotropin-releasing hormone in clonal pituitary cells. Proc Natl Acad Sci USA 82:4282-4286.

Escobedo JA, Barr PJ, Williams LT (1988) Role of tyrosine kinase and membrane-spanning domains in signal transduction by the platelet-derived growth factor receptor. Mol Cell Biol 8:5126-5131.

Fantl WJ, Escobedo JA, Martin GA, Turck CW, del Rosario M, McCormick F, Williams LT (1992) Distinct phosphotyrosines on a growth factor receptor bind to specific molecules that mediate different signalling pathways. Cell 69:413-423.

Fantl WJ, Johnson DE, Williams LT (1993) Signalling by receptor tyrosine kinases. Annu Rev Biochem 62:453-481.

Frace MA, Gargus J.J (1989) Activation of single-channel currents in mouse fibroblasts by platelet-derived growth factor. Proc Natl Acad Sci USA 86:2511-2515.

Garber SS, Hoshi T, Aldrich R (1989) Regulation of ionic currents in pheochromocytoma cells by nerve growth factor and dexamethasone. J Neurosci 9:3976-3987.

Gershengorn MC (1989) Mechanism of signal transduction by TRH. Ann NY Acad Sci 553:191-196.

Hatten ME, Lynch M, Rydel RE, Sanchez J, Joseph-Silverstein J, Moscatelli D, Rifkin DB (1988) In vitro neurite extension by granule neurons is dependent upon astroglial-derived fibroblast growth factor. Dev Biol 125:280-289.

Hoger JH, Walter AE, Vance D, Yu L, Lester HA, Davidson N (1991) Modulation of a cloned mouse brain potassium channel. Neuron $6: 227-236$.

Julius D (1991) Molecular biology of serotonin receptors. Annu Rev Neurosci 14:335-360.

Julius D, MacDermott AB, Axel R, Jessel TM (1988) Molecular characterization of a functional cDNA encoding the serotonin $1 \mathrm{c}$ receptor. Science 241:558-564.

Kaczmarck LK, Levitan IB (1987) Neuromodulation. New York: Oxford UP.

Kavanaugh MP, Christie MJ, Osborne PB, Busch AE, Shen K-Z, Wu $Y$-n, Seeburg PH, Adelman JP, North RA (1991) Transmitter regulation of voltage-dependent $\mathrm{K}^{+}$channels expressed in Xenopus oocytes. Biochem J 277:899-902.

Kim D, Lewis DL, Graziadei L, Neer EJ, Bar-Sagi D, Clapham DE (1989) G-protein beta gamma-subunits activate the cardiac muscarinic $\mathrm{K}^{+}$-channel via phospholipase $\mathrm{A}_{2}$. Nature 337:557-560.

Koch CA, Anderson D, Moran MF, Ellis C, Pawson T (1991) SH2 and SH3 domains: elements that control interactions of cytoplasmic signalling proteins. Science 252:668-674.

Lee PL, Johnson DE, Cousens LS, Freid VA, Williams LT (1989) Purification and complementary DNA cloning of a receptor for basic fibroblast growth factor. Science 245:57-60.
Lcvitan ES, Hemmick LM, Birnberg NC, Kaczmarek LK (1991) Dexamethasone increases potassium channel messenger RNA and activity in clonal pituitary cells. Mol Endocrinol 5:1903-1908.

Mandel G, Cooperman SS, Maue RA, Goodman RH, Brehm P (1988) Selective induction of brain type II $\mathrm{Na}^{+}$channels by nerve growth factor. Proc Natl Acad Sci USA 85:924-928.

Martin GA, Yatani A, Clark R, Conroy L, Polakis P, Brown AM, McCormack F (1992) GAP domains responsible for ras p21-dependent inhibition of muscarinic atrial $\mathrm{K}^{+}$channel currents. Science 255:192-194.

Mohammadi M, Dionne CA, Li W, Li N, Spivak T, Honegger AM, Jaye M, Schlessinger J (1992) Point mutation in FGF receptor eliminates phosphatidylinositol hydrolysis without affecting mitogenesis. Nature 358:681-684.

Nakajima Y, Nakajima S, Leonard RJ, Yamaguchi K (1986) Acetylcholine raises excitability by inhibiting the fast transient potassium current in cultured hippocampal neurons. Proc Natl Acad Sci USA 83:3022-3026.

Noble M, Murray K, Stroobant P, Waterfield MD, Riddle P (1988) Platelet-derived growth factor promotes division and motility and inhibits premature differentiation of the oligodendrocyte/type 2 astrocyte progenitor cell. Nature 333:560-562.

Pandiella A, Magni M, Lovisolo D, Meldolesi J (1989) The effects of epidermal growth factor on membrane potential. J Biol Chem 264: 12914-12921.

Peters KG, Marie J, Wilson E, Ives HE, Escobedo J, Del Rosario M, Mirda D, Williams LT (1992) Point mutation of an FGF receptor abolishes phosphatidylinositol turnover and $\mathrm{Ca}^{++}$flux but not mitogencsis. Nature 358:678-681.

Pollock JD, Krempin M, Rudy B (1990) Differential effects of NGF, FGF, EGF, cAMP and dexamethasone on neurite outgrowth and sodium channel expression in PC12 cells. J Neurosci 10:2626-2637.

Puro DG (1991) A calcium-activated, calcium-permeable ion channel in human retinal glial cells: modulation by basic fibroblast growth factor. Brain Res 548:329-333.

Puro DG, Mano T (1991) Modulation of calcium channels in human retinal glial cells by basic fibroblast growth factor: a possible role in retinal pathobiology. J Neurosci 11:1873-1880.

Raff MC, Sillien LE, Richardson WD, Burne JF, Noble MD (1988) Platelet-derived growth factor from astrocytes drives the clock that times oligodendrocyte development in culture. Nature 333:562-565.

Richardson WD, Pringle N, Mosley MJ, Westermark B, Dubois-Dalcq $M$ (1988) A rolc for platelet-derived growth factor in normal gliogenesis in the central nervous system. Cell 53:309-319.

Roth RA, Zhang B, Chin JE, Kovacina K (1992) Substrates and signalling complexes: the tortured path to insulin action. J Cell Biochem 48:12-18.

Smits A. Mitsuyasu K, Westermark B, Nister M, Heldin C-H, Funa K (1991) Neurotrophic activity of platelet-derived growth factor (PDGF): rat neuronal cells possess functional PDGF beta-type receptors and respond to PDGF. Proc Natl Acad Sci USA 88:8159-8163.

Swanson R, Marshall J, Smith JS, Williams JB, Boyle MB, Folander $\mathrm{K}$, Luneau CJ, Antanavage CO, Buhrow SA, Bennett C, Stein RB, Kaczmarek LK (1990) Cloning and expression of cDNA and genomic clones encoding three delayed rectifier potassium channels in rat brain. Neuron 4:929-939.

Taylor SJ, Chae HZ, Rhee SG, Exton JH (1991) Activation of the betal isozyme of phospholipase $C$ by alpha subunits of the $G_{a}$ class of $\mathrm{G}$ proteins. Nature 350:516-518.

Vu TKH, Hung DT, Wheaton VI, Coughlin SR (1991) Molecular cloning of a functional thrombin receptor reveals a novel proteolytic mechanism of receptor activation. Cell 64:1057-1068.

Walicke PA, Cowan WM, Ueno N, Baird A, Guillemin R (1986) Fibroblast growth factor promotes survival of dissociated hippocampal neurons and enhances neurite extension. Proc Natl Acad Sci USA 83:3012-3016.

Yarden Y, Escobedo JA, Kuang W-J, Yang-Feng TL, Daniel TO, Tremble PM, Chen FY, Ando ME, Harkins RN, Francke U, Fried VA, Ullrich A, Williams LT (1986) Structure of the receptor for plateletderived growth factor helps define a family of closely related growth factor receptors. Nature 323:226-232. 